\title{
Impact of managed realignment design on estuarine water levels
}

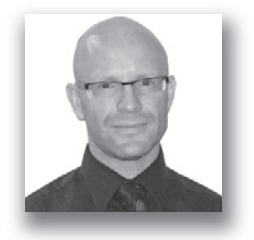

Nigel I. Pontee CEng, FICE, CWEM, CIWEM

Principal Coastal Scientist, CH2M, Burderop Park, Swindon, UK; Visiting

Professor, University of Southampton, Southampton, UK

Large realignment sites near the mouth of an estuary have the potential to raise water levels throughout the estuary. This increase is produced by the newly created intertidal area drawing additional water into the estuary on the flood tide. Although some of this additional water enters the realignment site, a proportion also bypasses the realignment site and continues upstream, thus increasing water levels in these areas of the estuary. The modelling results described in this paper suggest that an important determinant on estuary water levels is the rate at which the realignment site fills. Schemes that fill more slowly are predicted to have less impact than those that fill more rapidly, even if high water levels within the schemes are similar. For the schemes tested in this paper, the rate at which the site flooded appeared to depend less on breach dimensions and more on the width of the site that the flood waters had to cross in order to cause full inundation. It is proposed that those options with the shortest distances result in the flood tidal waters experiencing less frictional losses. These options showed a more rapid rise in water levels within the site, and produced a correspondingly larger increase in water levels within the estuary.

\section{Introduction}

In an estuarine context, the term 'managed realignment' is most commonly used to describe the process of deliberately removing flood defences and re-introducing tidal regimes to low-lying land previously reclaimed from the sea. Realignment schemes can make a valuable contribution to sustainable coastal management, potentially offering social and economic benefits as well as environmental gains (Pontee, 2007). Realignment schemes have been increasingly used to restore coastal habitats over the last 24 years in the UK (Esteves, 2014). In the future, the rate of implementation may increase further if the policies recommended by the current round of shoreline management plans are implemented in full. According to the Adaptation Sub-Committee (2013) the proposed managed realignment policies will create approximately 6200 ha by 2030 and 11500 ha by 2060 .

Over the last 20 years the body of literature on UK managed realignment schemes has grown substantially as more schemes have been implemented. The literature has covered design guides (Leggett et al., 2004) and lessons from existing schemes (e.g. Cooper, 2003; Dixon et al., 2008; Morris, 2013; Pontee, 2003, 2007; Rupp-Armstrong and Nicholls, 2007; Wheeler et al., 2008; Wolters et al., 2005). There are also online resources drawing together key facts and figures for different managed realignments (e.g., ABPmer, 2015). However, to date, the impact of managed realignment schemes on water levels in estuaries has not been widely documented in published literature. Changes in water levels may also be accompanied by changes in flow speeds, which can in turn impact on erosion/ accretion and morphology within an estuary. Changes in water levels can also potentially have impacts on flood risk and the extent of internationally protected intertidal habitats. It is therefore important to understand the factors that influence changes in water levels in order to design schemes successfully.

In the UK, the Environment Agency has developed flood risk management strategies for a number of estuaries. Many of these strategies have used numerical modelling to determine the impact of managed realignment on the hydrodynamic regimes. However, this work has usually remained within grey literature and is not readily accessible to the scientific community. One exception to this is Townend and Pethick (2002) who reported on some of the modelling work undertaken in support of the Humber Estuary flood risk management strategy (HFRMS). This work showed that large areas of managed realignment in the upper reaches of the Humber Estuary could reduce the height of extreme high water events. Conversely large areas of realignment near the mouth of the estuary were shown to cause increases in water levels. Subsequently the Alkborough flood storage scheme was developed as part of the programme of works arising from HFRMS (Wheeler et al., 2008). This scheme is located at the confluence of the River Ouse and River Trent and was predicted to reduce water levels on extreme events by around $10 \mathrm{~cm}$ at Blacktoft in the River 
Trent and Burton Stather in the River Ouse under a 1 in 100 year event (Environment Agency, 2005). Similar results have also been found in the Thames Estuary where a range of managed realignment and flood storage areas options were considered in the development of the Thames Estuary 2100 flood risk strategy plan (now in its implementation stage and known as the Thames Estuary plan) (Halcrow and HR Wallingford, 2006).

The present paper adds to this body of knowledge by considering the potential for managed realignments to increase water levels within an estuary. The paper considers the various breach options that were explored in the design of a managed realignment scheme in south west England. It explains the impacts of the different scheme options on estuarine water levels as predicted by hydrodynamic modelling.

\section{Study context}

The Steart Peninsula is located in Bridgwater Bay at the confluence of the Parret Estuary and the Bristol Channel (Figure 1). The area covers some 600 ha including farmland, high voltage power lines to the nearby Hinkley nuclear power station, a road and the small village of Steart. The peninsula is adjacent to the nationally and internationally designated areas. Hydrodynamic processes in the Parret Estuary are dominated by the large tidal range. At Hinkley, just to the west of the Parret Estuary mouth, the mean spring tidal range is $10.8 \mathrm{~m}$ (UK Hydrographic Office, 2013).

The Steart coastal management project, which was promoted by the Environment Agency, is creating new habitats and providing enhanced flood defences on the Steart Peninsula. The scheme was opened in September 2014 and is managed by the Wildfowl and Wetland Trust. The new habitats are required because existing designated intertidal habitats within the Bristol Channel and Severn Estuary are thought to be in the decline due to coastal squeeze. The new flood defences, which provide improved protection to the village of Steart and its access road, were required since some of the existing defences had as little as 5 years residual life left prior to the scheme being undertaken. The Steart coastal management project has created freshwater, brackish and intertidal habitats in different compartments separated by embankments (Figure 1). The scheme lies adjacent to another proposed habitat creation scheme (compartment A), which is being promoted by the Port of Bristol Authority (Wright et al., 2011). The present paper is concerned with the intertidal habitat that has been created within a breached managed realignment in compartment $\mathrm{D}$ on the eastern side of the peninsula.

\section{Realignment options considered}

Several approaches to reintroducing tidal waters to compartment $\mathrm{D}$ were considered during the design process. These included connecting the scheme to the Parret Estuary or to the Bristol Channel either directly by way of breaches, or indirectly by way of breaches into compartment A. Further details of the design process and the different options are given in Burgess et al. (2013). The final preferred option involved connecting the scheme directly to the Parret Estuary. A hydrodynamic modelling exercise was undertaken to develop a scheme that produced the maximum amount of intertidal habitat while minimising any increase in water levels in the wider estuary. The present paper is based on this work.

A number of options were modelled and these involved various numbers, sizes and locations of breaches from the Parret Estuary. Three breach locations were considered (Figure 2). These were labelled from the mouth of the estuary to upstream as $\mathrm{Br} 1, \mathrm{Br} 2$ and $\mathrm{Br} 3$, respectively. Each breach was connected to a creek system inside the realignment site. At the breach the creeks were typically $2.5 \mathrm{~m}$ deep (referenced to the surface elevation of the site around 7.07 metres above Ordnance Datum (mAOD)) and had widths of $100 \mathrm{~m}$. These dimensions decreased linearly to terminate at depths of approximately $1 \mathrm{~m}$ and widths of $10 \mathrm{~m}$ at their headward extent.

Various combinations of these breaches were considered (Table 1). For example, option 'Br1' only considered breach 1 being open, while option 'Br123' considered all three breaches being open. The individual breaches had the same cross-sectional area (CSA) in each option, with the exception of 'half Br13' in which the breaches each had half the CSA of the breaches in the other options. Thus, in general the single breach schemes had the smallest total CSA, while the threebreach scheme had the largest total CSA.

\section{Model set-up and validation}

A local 2D (two-dimensional) model of the Parret Estuary and its entrance was set up in the Mike21 FM (flexible mesh) HD module (DHI, 2011). The model had three open boundaries located within several kilometres offshore of the mouth of the Parret Estuary and extended upstream following the channel alignment to Bridgwater, just downstream from the point at which the M5 motorway crosses the Parret Estuary (Figure 1). The model was driven by water levels from a regional model of the Bristol Channel and Severn Estuary developed under the same software platform. The regional model covered the area from Frampton-on-Severn to the south east coast of Ireland (Figure 1). The model had previously been calibrated against water levels at Hinkley Point, Newport and Avonmouth, and against tidal diamond data in the Bristol Channel and St. George's Channel. Boundary data for astronomical tides were obtained from United Kingdom Hydrographic Office.

The local model was calibrated against observed current and water level data from fixed (acoustic Doppler current profiler) 


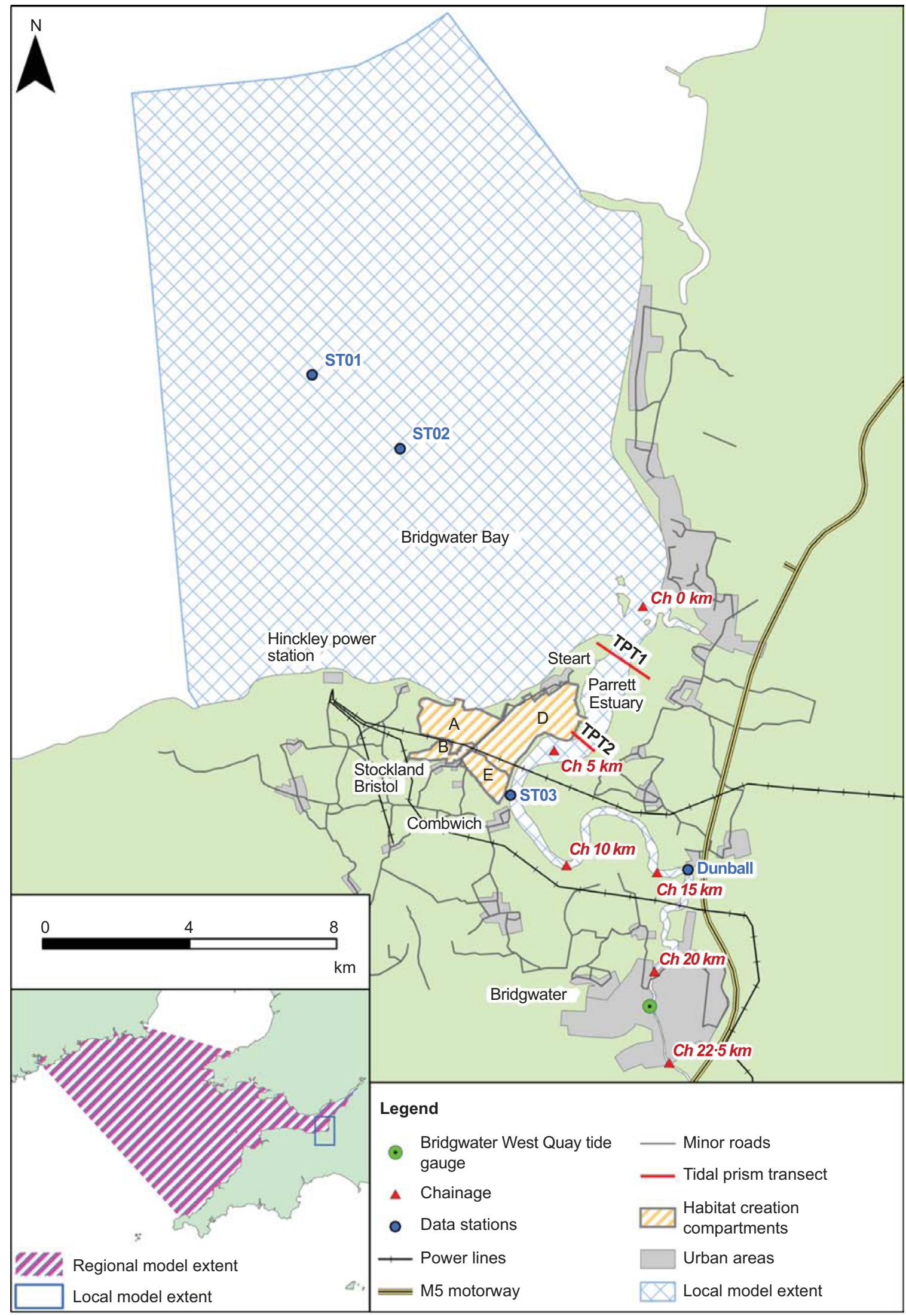


Maritime Engineering

Volume 168 Issue MA2
Impact of managed realignment design

on estuarine water levels

Pontee
Figure 1. Location plan showing position of study area in south west of the UK. The realignment site is located on the Steart Peninsula, which can be divided into four compartments. Compartment $A$ is the Port of Bristol Authority scheme (Wright et al., 2011). Compartments $B, D$ and $E$ form part of the Environment Agency scheme. Compartment $B$ is the freshwater habitat area. Compartment $E$ is the brackish water. Compartment $D$ is the intertidal area. Locations where hydrodynamic data were collected are also shown. Fixed instruments were deployed at ST01, ST02, ST03 over several weeks. Additional measurements were made over individual tides at the following locations synoptic 1 , synoptic 2 and Dunball. The insert shows the extent of the regional Mike21 FM model, which was used to drive the local model of the Parret Estuary. The regional model covered the Severn Estuary, the Bristol Channel and extended to the south east coast of Ireland. The local model consisted of three open boundaries located within the inner Bristol Channel, two shorenormal and one shore-parallel, aligned with typical streamlines in the area, and extends upstream to around $23 \mathrm{~km}$. The estuary/ channel cross-sections terminate at the location of the Parret Estuary defences and pressure transducers deployed in the Bristol Channel, Bridgwater Bay and the Parret Estuary from October to November 2010 (Figure 1). The model was verified against an independent tide gauge measurement at West Quay in Bridgwater for a storm event (December 1999), which corresponded to a 1 in 1 year event. Since the numerical model considered only tidal forcing (i.e. no metrological forcing) the measured data were processed to extract the astronomical tidal component, the resulting data are referred to as measured astronomical tidal values. For the fixed gauge at Hinkley Point - the astronomical tidal values were computed from the difference between the published time series of observation and residuals. These residuals were also applied to stations ST01 and ST02 located nearby. To derive astronomical tidal values for ST03, a harmonic analysis of the observed time series was undertaken to extract the tidal constituents. At the West Quay tide gauge in Bridgwater, the unaltered time series was used, since the issues of shallow water effects and base flow meant that there would have been too much uncertainty in using harmonic analysis to extract the tidal components.

Model calibration and verification was based on the Environment Agency guidelines (Environment Agency, 1998). For water levels the stringent absolute guide, within $0.1 \mathrm{~m}$ at the mouth and $0.3 \mathrm{~m}$ at the head of the estuary, was applied. For current speeds the comparable guidelines are $\pm 0.2 \mathrm{~m} / \mathrm{s}$.

The measured water level peaks were generally reproduced within $0.03 \mathrm{~m}$ for a typical neap-spring cycle and also during the December 1999 storm event (Figure 3). In comparison with water levels, the calibration for current speeds was less satisfactory, especially at ST01 in the Bristol Channel (Figure 4).

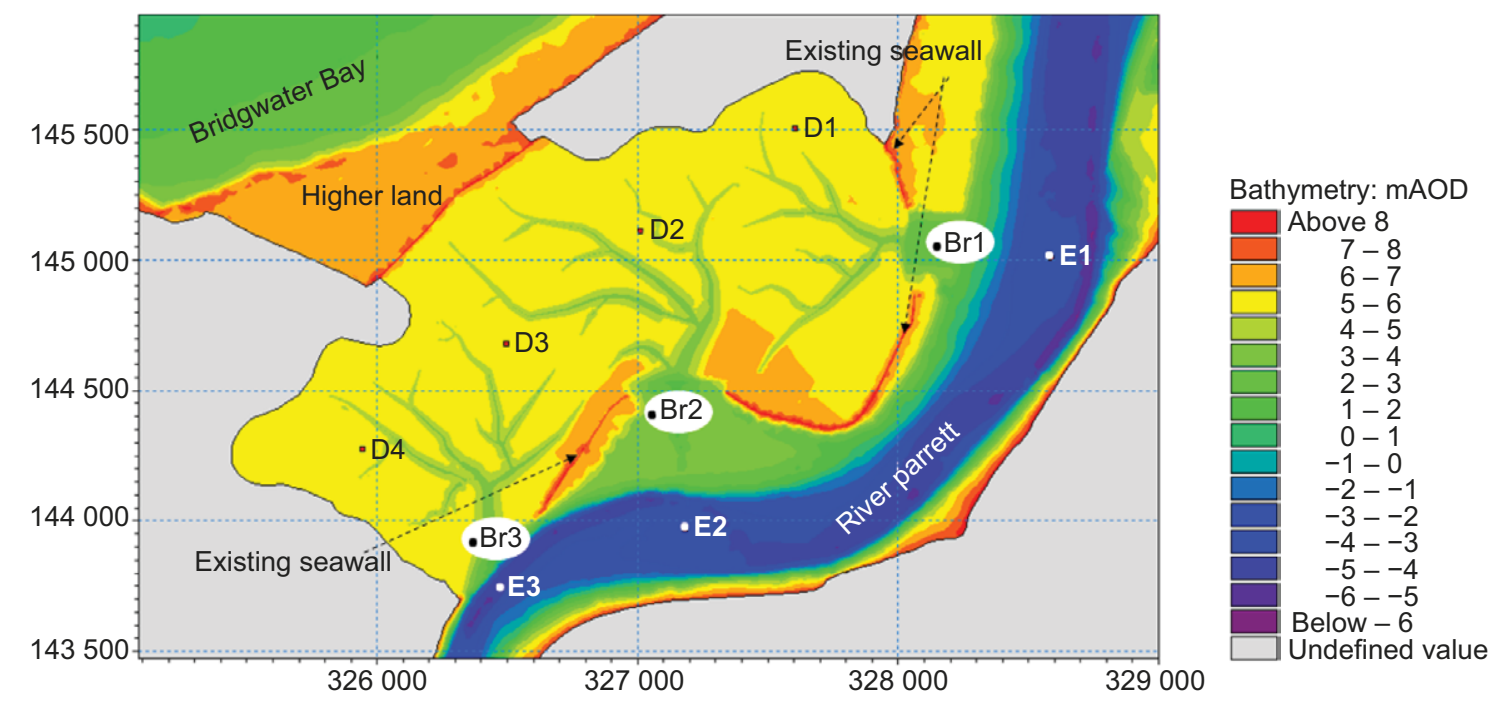

Figure 2. Realignment scheme on the Steart Peninsular. Figure shows the three breaches $(\mathrm{Br} 1, \mathrm{Br} 2, \mathrm{Br} 3)$ with creeks leading into the site. Locations D1 to D4 are data extraction points for water levels within the realignment scheme. Locations E1 to E3 are data extraction points in the Parret Estuary. Numbers on axis show Ordnance Survey grid references 
This may be attributable to differences in the actual and modelled bathymetry at this location. However, further inshore at ST02 in Bridgwater Bay the calibration was better. At ST03 within the Parret Estuary the model predictions compared well with measured values. Despite these limitations in current speed calibration, the model performance was considered sufficient for its primary purpose of evaluating potential increases in water level in the Parret Estuary. A number of runs was conducted for a 1 in 50 year and a 1 in 100 year event. The time series for these events was synthesised by scaling up the water levels from the 1999 time series.

\section{Results}

Figure 5 and Table 2 show the predicted impact of the different realignment options on water levels along the Parrett Estuary compared to the existing condition (solid black line) for the 1 in 50 year event. The modelling predicted that the options with a single north $(\mathrm{Br} 1)$ or south $(\mathrm{Br} 3)$ breach produced little, if any, increase in water levels within the estuary $(0-0.03 \mathrm{~m}$ at Combwich). By comparison, all of the options with two or three breaches produced larger increases (up to $0.20 \mathrm{~m}$ at Combwich). Option $\mathrm{Br} 2$, as a single centrally located breach, also produced larger increases in water levels at Combwich $(0 \cdot 15 \mathrm{~m})$ than option $\mathrm{Br} 1$ or $\mathrm{Br} 3$. A number of scheme options were considered under 1 in 100 year event (Figure 6 and Table 2). The results for the 1 in 100 year event were consistent with the above observations for the 1 in 50 year event. Additionally the half Br13 option, with reduced breach sizes, generated water level increases at Combwich $(0 \cdot 11 \mathrm{~m})$, which were similar to the full size $\mathrm{Br} 13$ option $(0 \cdot 12 \mathrm{~m})$. These results are discussed further in Section 6 .

As a primary reason for undertaking the scheme was to create intertidal habitats, another key aspect determining the suitability of different options was the degree to which they inundated the site. Initial inspection of maximum inundation plots under a 1 in 50 year event showed water levels within the scheme varied from approximately 7.85 mAOD to $8.05 \mathrm{mAOD}$ for the different options. For option $\mathrm{Br} 1$, the maximum water level in the scheme was 7.85-7.90 mAOD, while that for option $\mathrm{Br} 3$ was 7.95-8.00 mAOD. The remaining options produced similar levels of inundation, with maximum water levels within the scheme of between 7.95 and 8.05 mAOD. In discussion with the developer and the future site manager, these levels of inundation were accepted as being sufficient to create the desired amount of intertidal habitat within the scheme.

Closer inspection of water levels within the scheme under a 1 in 50 year event was made at the stations shown in Figure 2. Figure 7 and Table 2 show water levels at station D1 within the site for the same 1 in 50 year event. It can be seen that the timing of high water within the scheme; that is, the rate at which the scheme fills, varies between options. The key findings are as outlined below. 


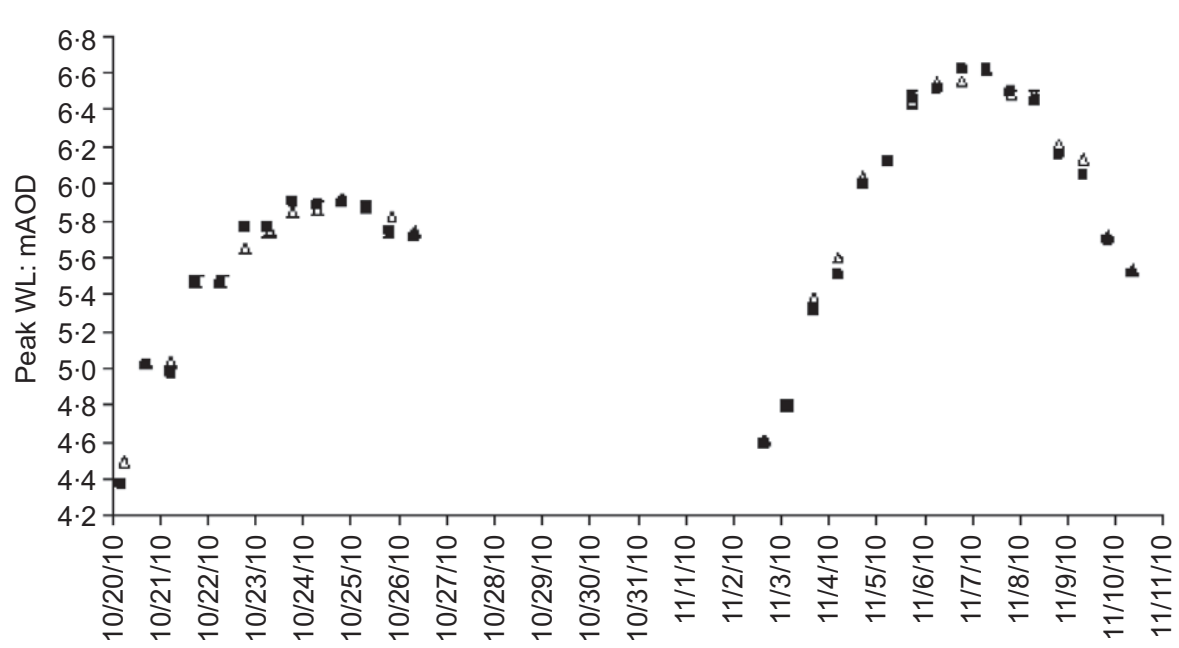

$\triangle$ Modelled peaks - Measured astronomical tide peaks $+0.38 \mathrm{~m}$

(a)

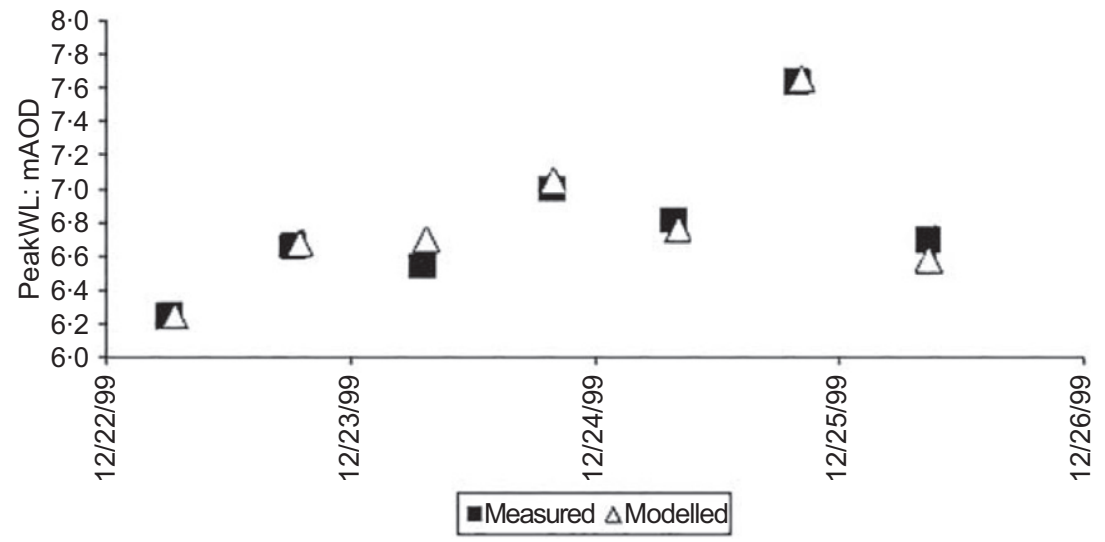

(b)

Figure 3. Comparison of measured astronomical tidal component and modelled tidal peaks: (a) at ST03; (b) at Bridgwater (West Quay tide gauge) during a storm event in December 1999

- Water levels increase upstream from the mouth of the estuary owing to the amplification of the tidal wave within the Parret Estuary. The peak water level occurs around $19 \mathrm{~km}$ from the estuary mouth. Upstream of this point high water levels decrease since by the time high water occurs here, the tide has already started to ebb at the mouth of the estuary. A steeper decrease occurs around $20 \mathrm{~km}$ upstream where there is a constriction in the estuary channel caused by a road bridge.

- For options $\mathrm{Br} 123, \mathrm{Br} 23, \mathrm{Br} 12$ and $\mathrm{Br} 13$, which all produced larger increases in water levels in the estuary, high water (HW) within the scheme occurred between 6.35 a.m. and 6.40 a.m.
For option $\mathrm{Br} 2$, which produced a higher impact on water levels in the main estuary, HW within the scheme occurred at 6.55 a.m. and reached $8 \mathrm{mAOD}$.

- For options Br1 and Br3, which produced much lower impacts on water levels in the estuary, HW within the scheme occurred between 7.00 a.m. and 7.05 a.m.

- Option Br23, which produced the largest increases in water levels in the estuary, also produced the highest HW within the scheme (8.04 mAOD).

- Option Br1, which produced the lowest increases in water levels in the estuary, produced the lowest HW levels in the site (7.83 mAOD). 


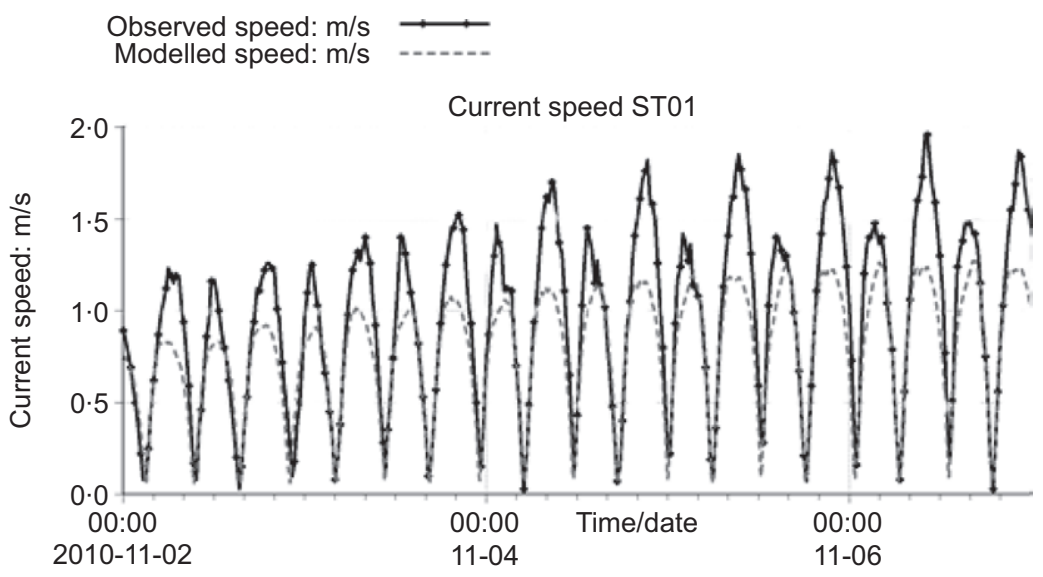

(a)

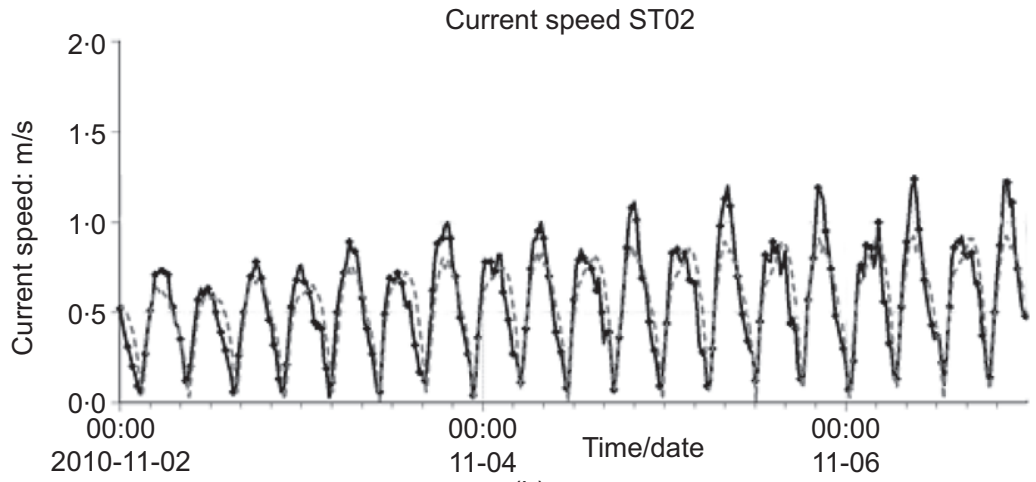

(b)

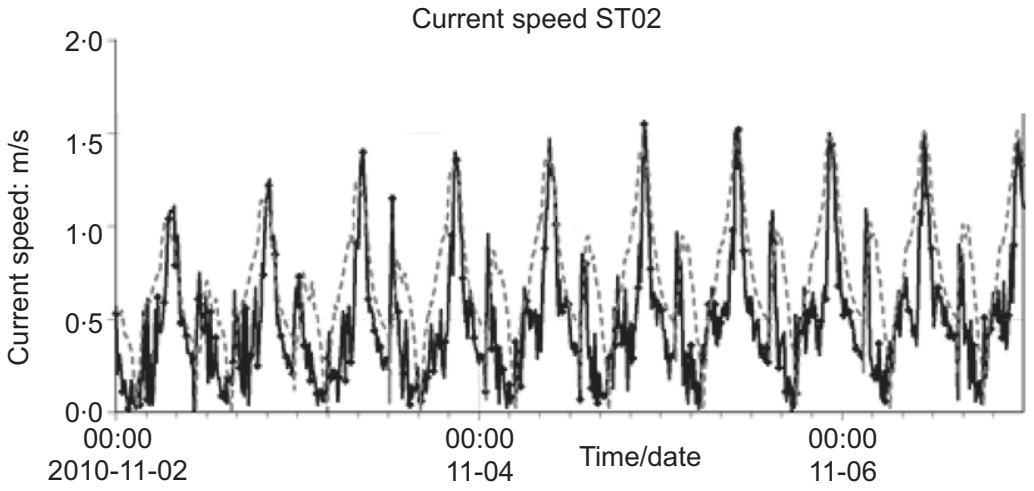

(c)

Figure 4. Current comparison at stations (a) ST01 in the Bristol Channel, (b) ST02 in Bridgwater Bay, and (c) ST03 in the

Parret Estuary

It can be seen that HW in the schemes occurred earliest for the options with two or more breaches. In comparison with these options, the option with a single centrally located breach (Br2) retarded the time of HW within the site by 15-20 min. For the options with a single breach at the north $(\mathrm{Br} 1)$ or south $(\mathrm{Br} 3), \mathrm{HW}$ within the scheme occurred some $25-30 \mathrm{~min}$ later.

To gain an understanding of the impact of the final managed realignment design (breach option $\mathrm{Br} 1$ ) on the estuary, an 


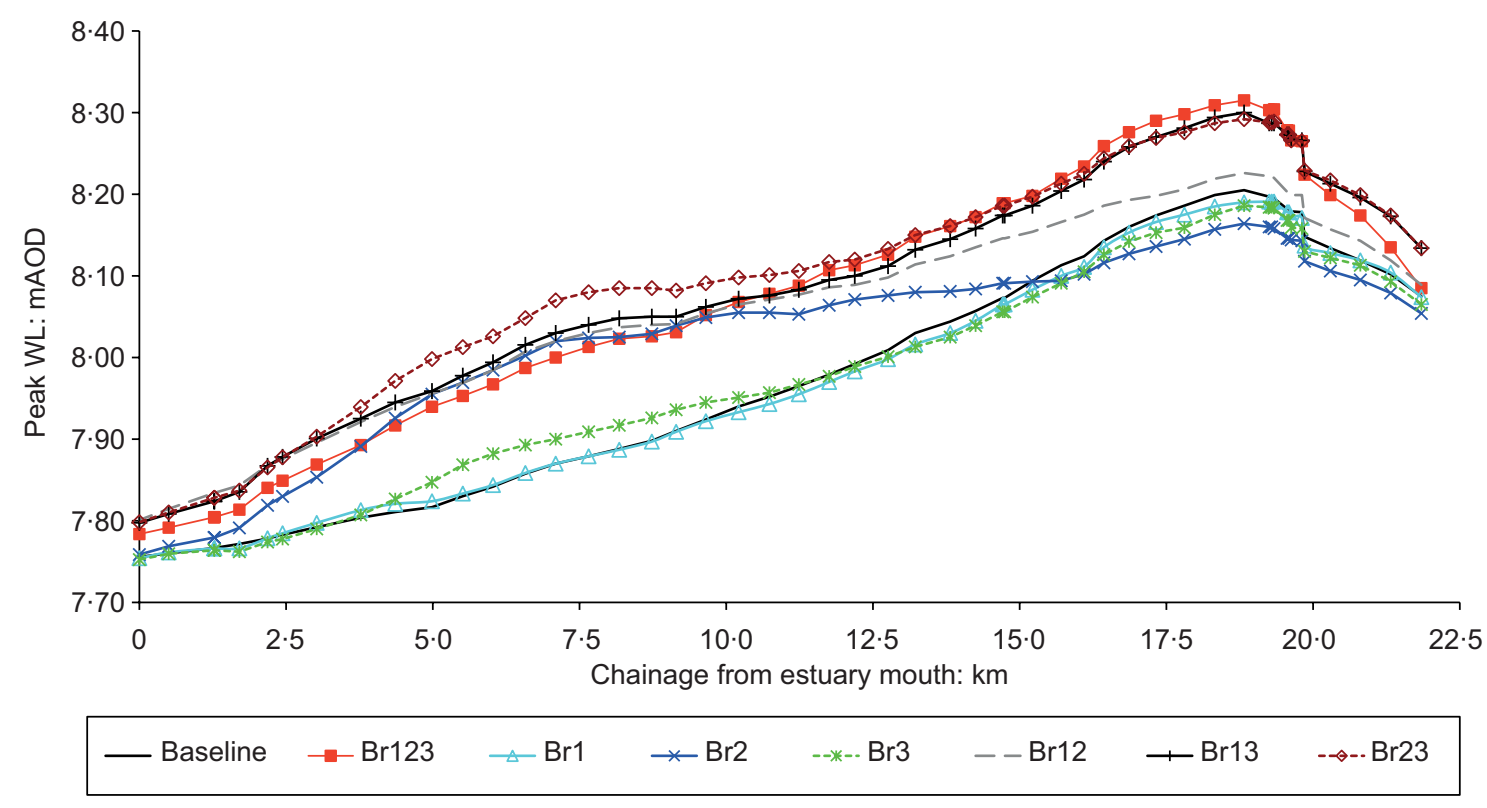

Figure 5. Water level changes resulting from the various options under a 1 in 50 year event

Total breach

dimensions width

for

1 in 50 year event

Option



in 50 year event

High water within scheme (location D1)

Width: $m$ CSA: $\mathrm{m}^{2}$ Height: mAOD Time (GMT)

\begin{tabular}{lllll}
\hline Br1 & 358 & 937 & $7 \cdot 83$ & 0700 \\
Br2 & 418 & 1214 & $8 \cdot 00$ & 0655 \\
Br3 & 416 & 1201 & 7.97 & 0705 \\
Br12 & 776 & 2151 & 7.95 & 0640 \\
Br23 & 834 & 2415 & 8.04 & 0640 \\
Br13 & 774 & 2138 & 7.95 & 0635 \\
Br123 & 1192 & 3352 & 7.92 & 0635 \\
Half Br13 & 387 & 1073 & & Not tested
\end{tabular}

Table 2. High water levels within the scheme and water level increases at chainage $7 \cdot 1 \mathrm{~km}$ (Combwich) in the Parret Estuary for various breach options. Data for water levels within scheme only available for 1 in 50 year run. See also Figures 5, 6 and 7
1 in 100 year event

High water Increase in

$\begin{array}{llll}\text { High water } & \text { Increase in } & \text { High water } & \text { Increase in } \\ \text { level in } & \text { water level } & \text { level in } & \text { water level }\end{array}$

Parrett Estuary over baseline Parrett Estuary over baseline

@ chainage condition@ @ chainage condition

$7.1 \mathrm{~km}: \mathrm{m} \quad$ of $7.87 \mathrm{~km}: \mathrm{m}$ of 7.96

$\begin{array}{llll}7.87 & 0.00 & 7.96 & 0.00 \\ 8.02 & 0.15 & 8.10 & 0.14 \\ 7.90 & 0.03 & 8.00 & 0.04\end{array}$

Not tested

Not tested

$8.07 \quad 0.20$

$8.03 \quad 0.16$

8.08

0.12

Not tested

$8.07 \quad 0.11$ 


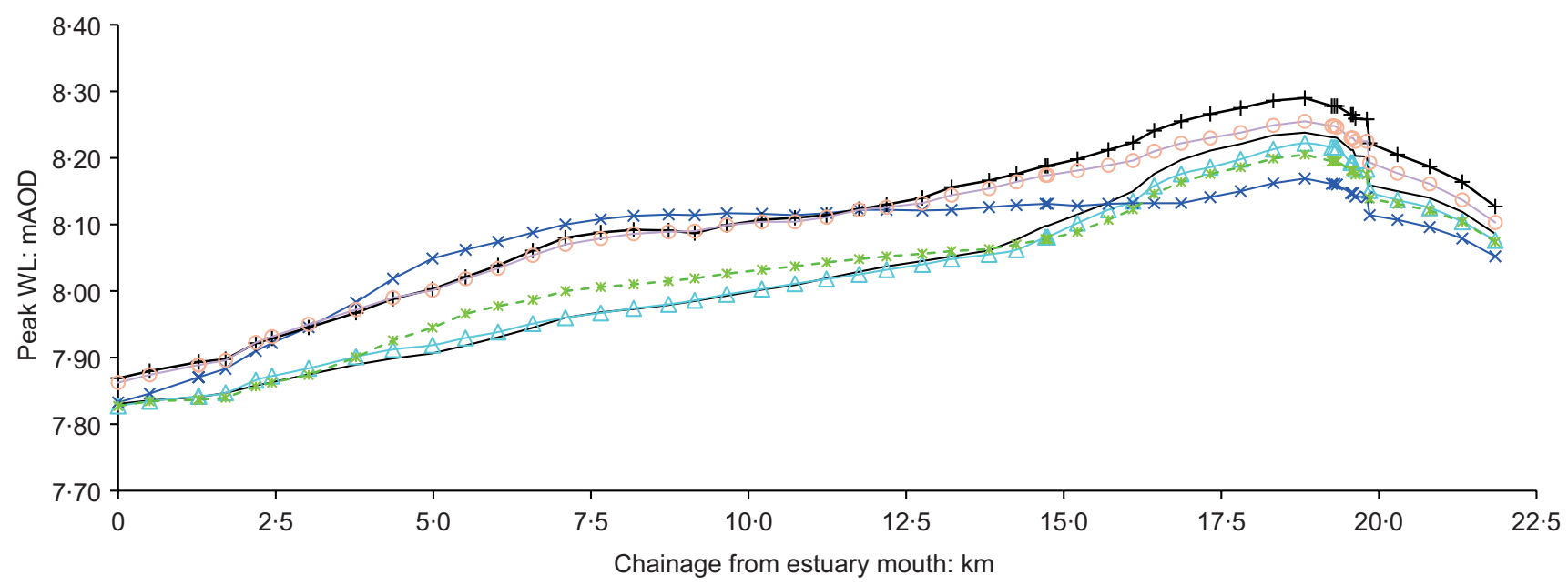

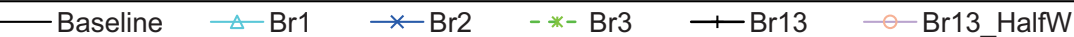

Figure 6. Water level changes in Parret Estuary resulting from the various managed realignment options under a 1 in 100 year event

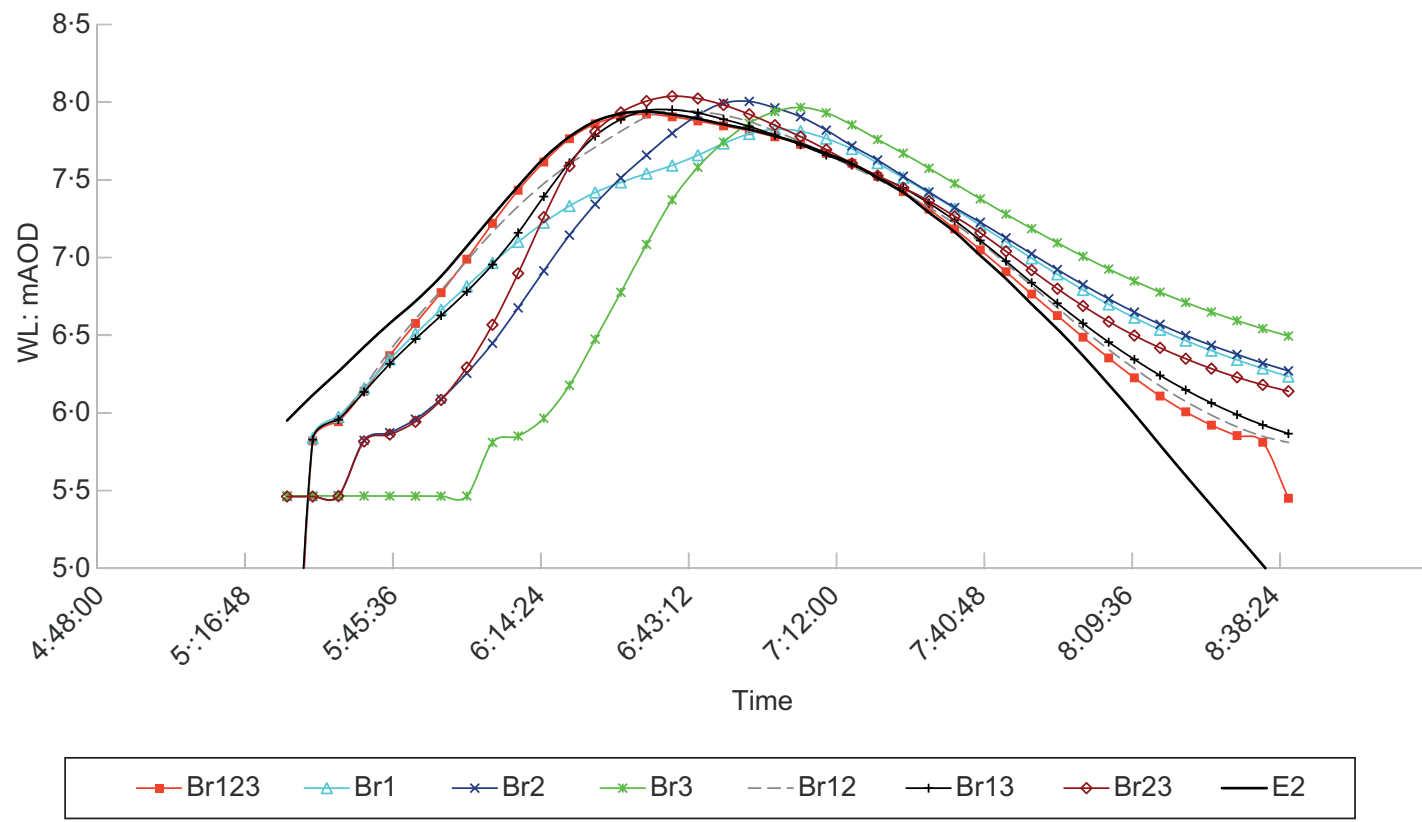

Figure 7. Water level variation at location D1 within the site for different scheme options under 1 in 50 year event. Water level at station E2 in the Parret Estuary for option Br123 shown for comparison 
investigation of the changes in tidal prism brought about by the scheme was made. The total flood tidal discharges were extracted from the hydrodynamic model for two cross-sections (Figure 1). Three tides were tested.

- An 'over-marsh tide' - that is a tide that exceeded the average elevation of the site (approximately $5.89 \mathrm{mOD}$ ) and caused waters to spill out of the creek network and inundate the majority of the site. This tide had a high water height of $6.26 \mathrm{mOD}$ at Hinkley Point.

- A mean spring tide with a high water of $5.89 \mathrm{mOD}$ at Hinkley Point that caused the creek system to fill to a 'bank-full level'.

- An 'under-marsh tide' where water was confined to the creek system within the site. This tide had a high water height of 5.31 mOD at Hinkley Point.

The results are shown in Table 3. It can be seen that the scheme increases the tidal prism of the Parrett Estuary but the majority of the additional volume is contained within the realignment site and the reach downstream of the breach. For the over-marsh tide the tidal prism upstream of the estuary mouth is increased by $4 \cdot 1 \%$, but upstream of the breach the prism is increased by just $0 \cdot 1 \%$.

\section{Discussion}

A key aspect determining the acceptability of the managed realignment scheme on the Steart Peninsula was that it should not increase water levels in the existing Parret Estuary. In absolute terms, a change in water levels of $0.2 \mathrm{~m}$ in an area where the spring tidal range exceeds $10 \cdot 5 \mathrm{~m}$ is small $(<2 \%)$.
However, there was concern that such changes could potentially be viewed by local stakeholders as increasing flood risk to land surrounding the Parret Estuary. Considerable efforts were therefore made during the design process to understand the impact of different designs on water levels and to develop designs with minimal impacts.

Previous work in the Humber (Townend and Pethick, 2002) and the Thames (Halcrow and HR Wallingford, 2006) has shown that large realignments near the mouths of estuaries can raise water levels within the wider estuary. This increase is produced by the newly created intertidal area drawing additional water into the estuary on the flood tide; that is, increasing the tidal prism. Although some of this additional water enters the realignment site, a proportion also bypasses the realignment site and continues upstream, thus increasing water levels in these areas of the estuary. The final chosen scheme on the Steart Peninsula $(\mathrm{Br} 1)$ is predicted to have a negligible impact on upstream tidal prism and water levels. For tides below mean high water spring level (MHWS) little of the site is inundated and impacts were undetectable. Even when tides exceed MHWS and inundate larger areas of the site, the additional volume of water entering and leaving the estuary mouth is predicted to be largely contained within the scheme and the reaches downstream of the scheme.

The outcome of the breach configuration modelling was that the options involving a single north or south breach were predicted to produce little, if any, increase in water levels within the estuary, whereas all of the options with one, two or three breaches produced increases of up to $0.2 \mathrm{~m}$. It might be

\begin{tabular}{|c|c|c|c|}
\hline Tidal condition & Transect & Increase in tidal prism: $\mathrm{m}^{3}$ & Increase in tidal prism as \% \\
\hline \multirow{3}{*}{$\begin{array}{l}\text { Over-marsh tide, HW } 6.26 \text { m } \\
\text { @ Hinkley Point }\end{array}$} & Estuary mouth & 1230000 & $4 \cdot 10$ \\
\hline & Estuary upstream of breach & 20000 & $0 \cdot 10$ \\
\hline & Remainder $^{a}$ & 1210000 & $\mathrm{~N} / \mathrm{A}$ \\
\hline \multirow[t]{3}{*}{ MHWS , HW 5.89@ Hinkley Point } & Estuary mouth & 616000 & $2 \cdot 20$ \\
\hline & Estuary upstream of breach & 12600 & 0.07 \\
\hline & Remainder $^{a}$ & 603400 & $\mathrm{~N} / \mathrm{A}$ \\
\hline \multirow{3}{*}{$\begin{array}{l}\text { Under-marsh tide), HW } 5.31 \text { m } \\
\text { @ Hinkley Point }\end{array}$} & Estuary mouth & 312500 & $1 \cdot 25$ \\
\hline & Estuary upstream of breach & 19200 & $0 \cdot 12$ \\
\hline & Remainder $^{a}$ & 293300 & $\mathrm{~N} / \mathrm{A}$ \\
\hline
\end{tabular}

andicates the tidal prism increase that must be contained with the managed realignment scheme and the reach of the estuary between the two transects.

Table 3. Increase in tidal prism for the final scheme design - a

single northern breach $(\mathrm{Br} 1)$ 
expected that the upstream water level increases would be dependent on the total CSA of the breach scenarios. However, a number of observations show this not to be the case for the range of options tested here.

- Under a 1 in 50 year event the largest increases in estuary water levels were predicted for option $\mathrm{Br} 23$ (rather than option Br123 that had a larger total CSA).

- For both the 1 in 50 and 1 in 100 year events, the single breach at a central location $(\mathrm{Br} 2)$, produced large increases in water levels,

- For the 1 in 100 year event, the half Br13 option, with reduced breach sizes, generated water level increases at Combwich $(0.11 \mathrm{~m})$, which were similar to the full-size Br13 option $(0 \cdot 12 \mathrm{~m})$

That the CSA of the various breach combinations tested did not appear to influence the increase in water level in the main estuary, suggests that all options considered in this analysis were sufficient to allow the site to be fully inundated. It is possible that if a range of smaller breach CSAs had been tested a greater difference in impact on water level increases in estuary would have been seen.

The options that produced larger impacts on water levels in the main estuary had either a centrally located breach (option $\mathrm{Br} 2$ ) or multiple breaches (options $\mathrm{Br} 12, \mathrm{Br} 13, \mathrm{Br} 23, \mathrm{Br} 123$ ). High water for these schemes occurred earlier suggesting that the schemes filled more rapidly. It is suggested that this faster filling was attributable to the incoming tidal waters having to cross a lesser width of the site in order to achieve full site inundation (Figure 8(a) and (b)).

The options that generated the smallest impact on water levels in the main estuary were $\mathrm{Br} 1$, which had a single breach at the northern end of the site; and $\mathrm{Br} 3$, which had a single breach at the southern end of the site. High water within each of these schemes occurred later, suggesting that the schemes took longer to fill on the flood tide. It is suggested that this slower filling was due to the incoming tidal waters having to cross a greater width of the site in order to achieve full site inundation (see Figure 8(c) and 8(d))

One might expect schemes that led to higher HW levels within them (i.e. contained larger volumes of water at high water) to lead to greater impacts on water levels in the main estuary. There is some evidence for this in that option $\mathrm{Br} 23$, which produced the largest increases in water levels in the estuary, had the highest HW levels within the scheme. Furthermore, option $\mathrm{Br} 1$ had the lowest HW levels within the scheme and produced the smallest increases in water levels in the Parret Estuary. However, option $\mathrm{Br} 3$ produced HW levels that were comparable to options $\mathrm{Br} 13$ and $\mathrm{Br} 12$ (although they occurred some
25-30 min later). Further investigations are therefore needed to clarify the relative importance of maximum inundation volume and the rate of infilling of managed realignment sites on water levels within estuaries.

The permanency of any increases in water levels within the main estuary has not been investigated in the present paper. Within an estuary system, form and process are linked. Thus changes in hydrodynamics might be expected to lead to changes in channel morphology. These changes have the potential to return the hydrodynamics to the pre-intervention condition or a new condition. Further work is needed to evaluate the long-term impact of managed realignment schemes on estuary hydrodynamics and morphology. Such work will be important for determining whether the resulting impacts, such as changes in water levels and flow speeds, are likely to be permanent or temporary. Understanding these impacts is particularly important given the large areas of realignment proposed by the current round of shoreline management plans.

\section{Conclusion}

The proposed managed realignment on the Steart Peninsula is a large realignment area located at the mouth of a hyper-tidal estuary. The modelling tests described in the present paper demonstrate that some breach options had the potential to increase water levels in the estuary. This increase was produced by the newly created intertidal area drawing additional water into the estuary on the flood tide.

The predicted impact on water levels within the estuary varied from virtually zero to an increase of $0.2 \mathrm{~m}$ for the different options tested. The only options that did not produce this increase were a single breach at either of the extremities of the site; that is, a breach at the northern end or a breach at the southern end. The chosen scheme design, which was opened to tidal action in September 2014, was a single breach at the northern end of the site.

For the options tested, the key factor determining the magnitude of water level increases in the estuary appeared to be the rate at which the site filled on the flood tide. The most important control on the rate of site filling appeared to be the location and number of breaches relative to the interior dimensions of the site. Together, these parameters control the distance that water has to travel across the site, and thus the amount of frictional drag that the incoming flood waters experience. Interestingly, for the options tested, these factors were more important in governing the resulting impacts on water levels than the total combined cross-sectional areas of the breach scenario. The smallest predicted increases in water level in the Parret Estuary were generated by those options that filled more slowly and had a single breach at either end of the site. For these options, HW within the scheme occurred 


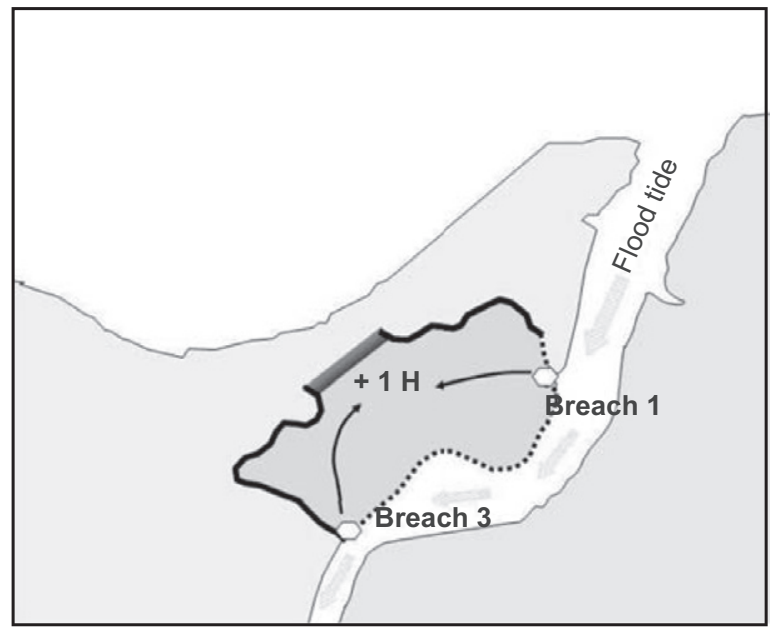

(a)

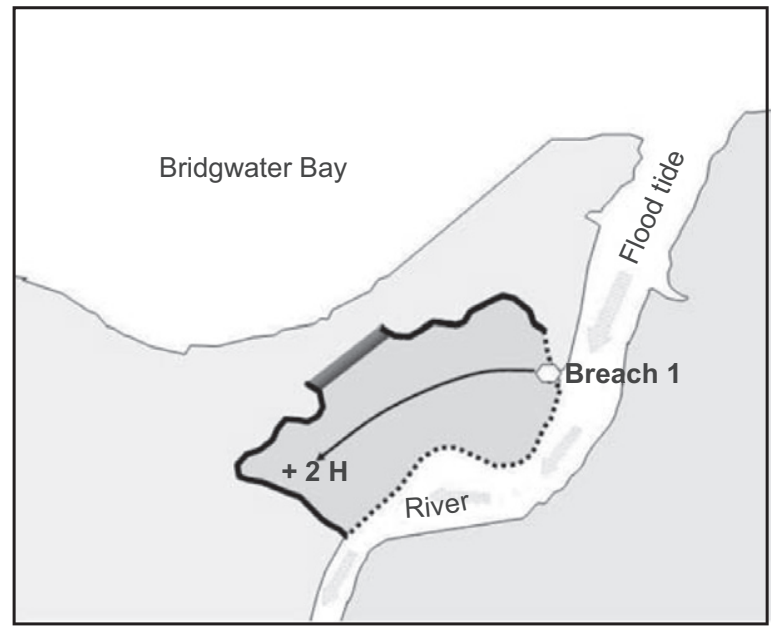

(c)

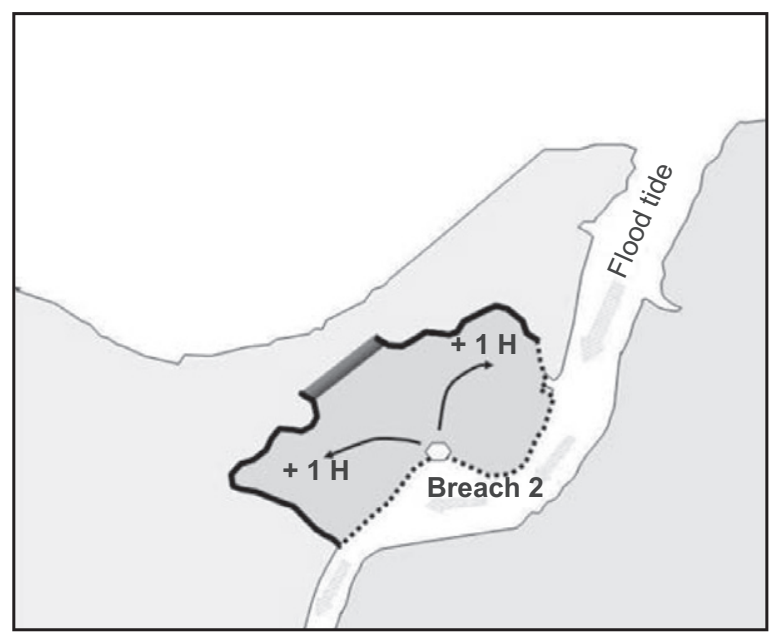

(b)

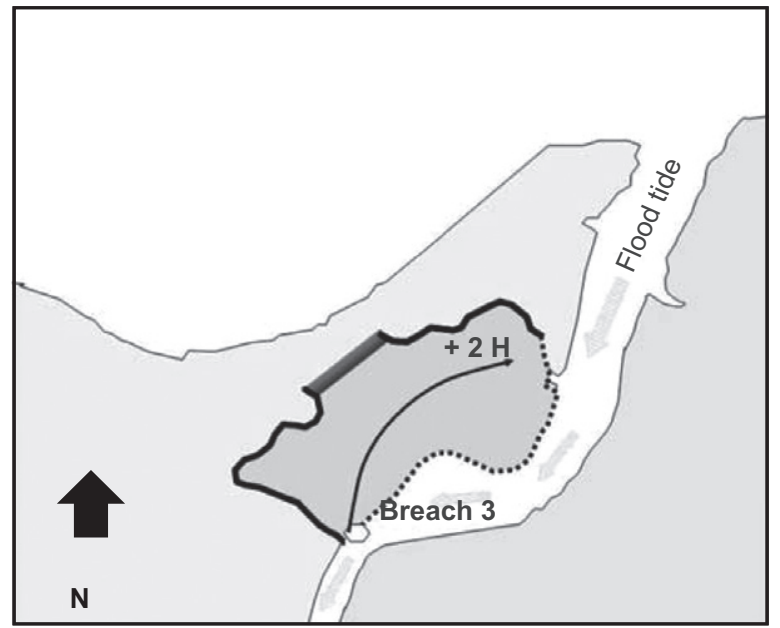

(d)

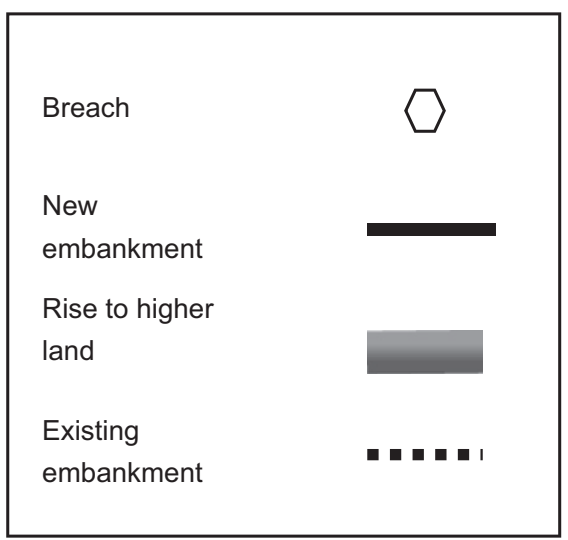

larger increases in water levels within the estuary. (a) A two breach option ( $\mathrm{Br} 13)$; (b): a single central breach option ( $\mathrm{Br} 2)$; (c) a single breach option $(\mathrm{Br} 1)$; (d): a single breach option ( $\mathrm{Br} 3)$ inundation times. The arrows indicate simplified flow paths for water entering the site on the flood tide. Options that have shorter flow paths fill more rapidly on the flood tide and create 
later in the flood tide. Conversely, the largest predicted increase in waters levels in the main estuary occurred under options that filled more rapidly. For these options the HW within the scheme occurred earliest in the flood tide.

Although managed realignment schemes have been carried out for 24 years in the UK, a full understanding of the impacts of such schemes of hydrodynamics on estuaries is still lacking. This paper confirms that managed realignments that lead to the significant expansion of intertidal areas near estuary mouths can alter the tidal propagation within estuaries leading to increases in water levels. These effects would be expected to apply to other hyper- and macro-tidal estuaries.

The results described here also demonstrate why it is necessary to carrying out numerical modelling early in the design process in order to minimise the hydrodynamics impacts of large schemes on the surrounding estuary. Further work is, however, needed to evaluate the how breach configurations influence the water levels within in other estuary environments. Specifically, the relative importance of the rate of site infilling and the total volume of inundation needs to be better understood. Further work is also required to establish whether the hydrodynamic impacts with the wider estuary are likely to be permanent or whether they have the potential to return to pre-intervention levels following a period of morphological adjustment within the estuary channel. Pre- and postscheme field data are also needed to support modelling predictions.

\section{Acknowledgements}

This paper is based on work completed for the Environment Agency as part of the Steart coastal management project. The views expressed within this paper are those of the author alone. The author is grateful to Say Chong Lee and other $\mathrm{CH} 2 \mathrm{M}$ staff who contributed to the modelling work including Kevin Burgess, Darren Price and Toby Wilson. The author is grateful to Alex Whiting, Martin Costello and Thomas Barker who prepared a number of the figures.

\section{REFERENCES}

Adaptation Sub-Committee (2013) Progress Report 2013

Managing the Land in a Changing Climate. Adaptation Sub-Committee. Committee on Climate Change, London, UK. See http://www.theccc.org.uk/wp-content/uploads/2013/ 07/ASC-2013-Book-singles_2.pdf (accessed 03/03/2015).

ABPmer (ABP Marine Environmental Research Ltd) (2015) http:// www.abpmer.net/omreg (accessed 18/05/2015).

Burgess B, Pontee N, Wilson T, Lee SC and Cox R (2013) Steart coastal management project: engineering challenges in a hyper-tidal environment. In From Sea to Shore-Meeting the Challenges of the Sea (Allsop W and Burgess K (eds)). ICE Publishing, London, UK, pp. 665-674.
Cooper NJ (2003) The use of 'managed retreat' in coastal engineering. Proceedings of the Institution of Civil Engineers - Engineering Sustainability 156(2): 101-110.

DHI (2011) Mike by DHI. Mike 21 Flow Model FM, Hydrodynamic Module, User Guide. DHI, Hørsholm, Denmark.

Dixon AMRK, Morris CR, Scott A, Birchenough SA and Colclough S (2008) Lessons learned from Wallasea, UK. Proceedings of the Institution of Civil Engineers - Maritime Engineering 161(2): 61-71, http://dx.doi.org/10.1680/maen.2008.161.2.61 Environment Agency (1998) Quality Control Manual for Computational Estuarine Modelling. Environment Agency, London, UK, Technical Report W168. See http:/www. freshwaterlife.org/projects/media/projects/images/2/30871_ ca_object_representations_media_229_original.pdf (accessed 26/07/2013).

Environment Agency (2005) Project Appraisal Report. Humber Estuary Tidal Defences Alkborough Tidal Defence Scheme. Environment Agency, London, UK, Report prepared by Halcrow for the Environment Agency-North East Region, Agency Project Code: IMPFH08000.

Esteves LS (2014) The need for adaptation in coastal protection: shifting from hard engineering to managed realignment. In Managed Realignment: A Viable LongTerm Coastal Management Strategy? Springer, New York, NY, USA, chapter 1.

Halcrow and HR Wallingford (2006) Thames Estuary 2100. Early Conceptual Options: Responses Affecting Water Levels: Initial Tests, ECO Report R1. Report produced by Halcrow Group Ltd and HR Wallingford Ltd for the Environment Agency, London, UK.

Hayes MO (1975) Morphology of sand accumulations in estuaries. In Estuarine Research. Volume II: Geology and Engineering (Cronin LE (ed.)). Academic Press, NY, USA, pp. 3-22.

Leggett DJ, Cooper NJ and Harvey R (eds) (2004) Coastal and Estuarine Managed Realignment: Design Issues. Ciria Publications, London, UK, C628.

Morris RKA (2013) Managed realignment as a tool for compensatory habitat creation $-\mathrm{A}$ re-appraisal. Ocean \& Coastal Management 73(8): 82-91.

Pontee NI (2003) Designing sustainable estuarine intertidal habitats. Proceedings of the Institution of Civil Engineers Engineering Sustainability 156(3): 157-167.

Pontee NI (2007) Realignment in low lying coastal areas: Experiences from the UK. Proceedings of the Institution of Civil Engineers - Maritime Engineering 160(4): 155-166, http://dx.doi.org/10.1680/maen.2007.160. 4.155 .

Rupp-Armstrong S and Nicholls RJ (2007) Coastal and estuarine retreat: A comparison of the application of managed realignment in England and Germany. Journal of Coastal Research 23(6):1418-1430. 
Townend I and Pethick J (2002) Estuarine flooding and managed retreat. Philosophical Transactions of the Royal Society of London 360: 1477-1495.

United Kingdom Hydrographic Office (2013) Admiralty Tide tables United Kingdom and Ireland (including European Channel Ports). The United Kingdom Hydrographic Office, Taunton, UK, vol. 1, NP201-13.

Wheeler D, Tan S, Pontee N and Pygott J (2008) Alkborough scheme reduces extreme water levels in the Humber Estuary and creates new habitat. Proceedings of FLOODrisk 2008 - The European Conference on Flood Risk Management Research into Practice, Oxford, UK.
Wolters M, Garbutt A and Bakker JP (2005) Salt-marsh restoration: evaluating the success of de-embankments in north-west Europe. Biological Conservation 123(2): 249-268.

Wright A, Shipton J, Carroll B and Armstrong S (2011) Lessons for designing managed realignment sites along hyper tidal estuaries - A case study on the Bristol Port Company's Steart habitat creation scheme. In Innovative Coastal Zone Management: Sustainable Engineering for a Dynamic Coast (Schofield A (ed.)). ICE Publishing, London, UK, pp. 233-242.

\section{WHAT DO YOU THINK?}

To discuss this paper, please email up to 500 words to the editor at journals@ice.org.uk. Your contribution will be forwarded to the author(s) for a reply and, if considered appropriate by the editorial panel, will be published as discussion in a future issue of the journal.

Proceedings journals rely entirely on contributions sent in by civil engineering professionals, academics and students. Papers should be 2000-5000 words long (briefing papers should be 1000-2000 words long), with adequate illustrations and references. You can submit your paper online via www.icevirtuallibrary.com/content/journals, where you will also find detailed author guidelines. 